\title{
Creative Commons Licences
}

\author{
Sascha Friesike
}

\begin{abstract}
Licences are a topic many researchers shy away from. And it is common behavior that property rights are unknowingly signed away. In this little section we would like to present the different creative commons licences one is oftentimes confronted with. This book for instance is published under a creative commons license. They are widely used and especially popular online and it is helpful to any researcher to understand what they mean.
\end{abstract}

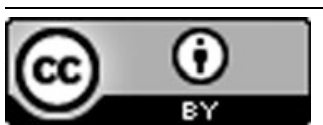

Attribution CC BY

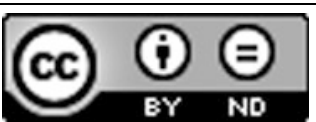

Attribution-NoDerivs CC BY-ND

This license allows for redistribution, and build upon your work, even commercially, as long as they credit you for the original creation. This is the most accommodating of licenses offered. Recommended for maximum dissemination and use of licensed materials

(continued)

\footnotetext{
S. Friesike $(\square)$

Alexander von Humboldt Institute for Internet and Society, Berlin, Germany e-mail: friesike@hiig.de
} 


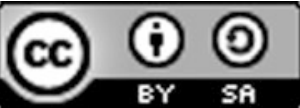

\section{Attribution-ShareAlike CC BY-SA}

This license lets others remix, tweak, and build upon your work even for commercial purposes, as long as they credit you and license their new creations under the identical terms. This license is often compared to "copyleft" free and open source software licenses. All new works based on yours will carry the same license, so any derivatives will also allow commercial use.

This is the license used by Wikipedia, and it is recommended for materials that would benefit from incorporating content from Wikipedia and similarly licensed projects

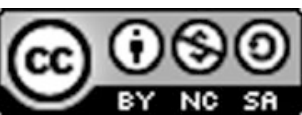

Attribution-NonCommercial-ShareAlike CC BY-NC-SA

This license lets others remix, tweak, and build upon your work non-commercially, as long as they credit you and license their new creations under the identical terms

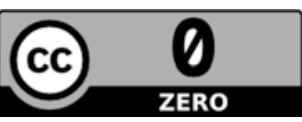

\section{No Copyright: Public Domain CC0}

The person who associated a work with this deed has dedicated the work to the public domain by waiving all of his or her rights to the work worldwide under copyright law, including all related and neighboring rights, to the extent allowed by law. You can copy, modify, distribute and perform the work, even for commercial purposes, all without asking permission

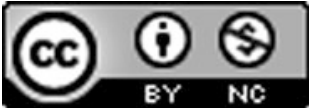

Attribution-NonCommercial CC BY-NC

This license lets others remix, tweak, and build upon your work non-commercially, and although their new works must also acknowledge you and be non-commercial, they don't have to license their derivative works on the same terms

\section{$\propto \oplus \Theta \Theta$ BY NC ND}

\section{Attribution-NonCommercial-NoDerivs CC BY-NC-ND}

This license is the most restrictive of our six main licenses, only allowing others to download your works and share them with others as long as they credit you, but they can't change them in any way or use them commercially

You can find more information on the well curated website of www.creativecommons.org where all the licences descriptions stem from. And here: http://www.nejm.org/doi/full/10.1056/NEJMp1300040.

Open Access This chapter is distributed under the terms of the Creative Commons Attribution Noncommercial License, which permits any noncommercial use, distribution, and reproduction in any medium, provided the original author(s) and source are credited. 